\title{
RP-HPLC Method Development and Validation for the Analyisis of Pharmaceutical Drug - ACECLOFENAC
}

\author{
Ami R Patel ${ }^{1}$, Dr. V G Patel ${ }^{2}$ \\ Chemistry Department, Municipal Arts and Urban Science College, Mehsana, Gujarat, India
}

\begin{abstract}
A simple, selective, linear, precise and accurate RP-HPLC method was developed and validated for rapid assay of ACECLOFENAC. Isocratic elution at a flow rate of $1.2 \mathrm{ml} / \mathrm{min}$ was employed on a symmetry C18 column at ambient temperature. The mobile phase consisted of Acetonitrile: 0.1M Acetic Acid 60:40 (v/v). The UV detection wavelength was at 210 nm. Linearity was observed in concentration range of $0.01-0.05 \mathrm{gm} / \mathrm{ml}$. The retention time for ACECLOFENAC was 3.0 min. The method was validated as per the ICH guidelines. The proposed method can be successfully applied for the estimation of ACECLOENAC.
\end{abstract}

Keywords: Aceclofenac, Method Development, Validation, 210nm, 3.0min.

\section{Introduction}

DRUGS: Aceclofenac<smiles>O=C(O)COC(=O)Cc1ccccc1Nc1c(Cl)cccc1Cl</smiles>

\begin{tabular}{|c|c|}
\hline IUPAC Name & $\begin{array}{c}\text { [[[2-[(2,6-Dichlorophenyl)amino]phenyl] } \\
\text { acetyl]oxy]acetic acid }\end{array}$ \\
\hline Formula & $\mathrm{C}_{16} \mathrm{H}_{13} \mathrm{Cl}_{2} \mathrm{NO}_{4}$ \\
\hline Molacular Weight & $353.03 \mathrm{~g} / \mathrm{mol}$ \\
\hline Density & $1.455 \mathrm{~g} / \mathrm{cm}^{3}$ \\
\hline Melting Point & $149-153^{0} \mathrm{C}^{[2]}$ \\
\hline Solubility & $\begin{array}{c}\text { Practically insoluble in water, freely soluble in } \\
\text { acetone, soluble in alcohol. }\end{array}$ \\
\hline
\end{tabular}

Aceclofenac is a non-steroidal anti-inflammatory drug (NSAID) analog of Diclofenac. It is used for the relief of pain and inflammation in rheumatoid arthritis, osteoarthritis and ankylosing spondylitis.

It should not be given to people with porphyria or breastfeeding mothers, and is not recommended for children. It should be avoided near term in a pregnant woman because of the risk of having a patent ductus arteriosus in the neonate.

The drug works by inhibiting the action of cyclooxygenase $(\mathrm{COX})$ that is involved in the production of prostaglandins (PG) which is accountable for pain, swelling, inflammation and fever. The incidence of gastric ulcerogenicity of aceclofenac has been reported to be significantly lower than that of the other frequently prescribed NSAIDs, for instance, 2-folds lesser than naproxen, 4-folds lesser than diclofenac, and 7-folds lesser than indomethacin. Aceclofenac
(C16H13Cl2NO4), chemically $[(2-\{2,6$-dichlorophenyl $)$ amino phenylacetooxyacetic acid], is a crystalline powder with a molecular weight of 354.19. It is practically insoluble in water with good permeability. It is metabolized in human hepatocytes and human microsomes to form [2- $\left(2^{\prime}, 6^{\prime}-\right.$ dichloro-4'-hydroxy- phenylamino) phenyl] acetoxyacetic acid as the major metabolite, which is then further conjugated. According to the Biopharmaceutical Classification System (BCS) drug substances are classified to four classes upon their solubility and permeability. Aceclofenac falls under the BCS Class II, poorly soluble and highly permeable drug.

\section{Experimental}

\section{Chemicals and reagents}

All HPLC SOLVENTS used like Acetonitrile, Acetic Acid which are of HPLC grade were purchased from E.Merck,

\section{Instrumentation and analytical conditions}

The analysis of the drug was carried out on Shimadzu HPLC model (VP series) containing LC-20AT (VP series) pump, variable wave length programmable $\mathrm{UV} /$ visible detector SPD-20A and rheodyne injector (7725i) with $20 \mu$ lixed loop. Chromatographic analysis was performed using phenolex C-18 column with 250 x $4.6 \mathrm{~mm}$ internal diameter and $5 \mu \mathrm{m}$ particle size. Shimadzu electronic balance (AX200) was used for weighing. Isocratic elution with, Acetonitrile, 0.1MAcetic Acid 60:40(v/v) was selected with a flow rate of $1.2 \mathrm{ml} / \mathrm{min}$. The detection wavelength was set at $210 \mathrm{~nm}$ with a run time of $10 \mathrm{~min}$. The mobile phase was prepared freshly and it was degassed by sonicating for $5 \mathrm{~min}$ before use. The column was equilibrated for at least $30 \mathrm{~min}$ with the mobile phase flowing through the system. The column and the HPLC system were kept at ambient temperature. 


\section{International Journal of Science and Research (IJSR) \\ ISSN (Online): 2319-7064 \\ Index Copernicus Value (2015): 78.96 | Impact Factor (2015): 6.391}

Preparation of Stock, working standard solutions and Sample solutions

$100 \mathrm{mg}$ of Aceclofenac was weighted and transferred into a $100 \mathrm{ml}$ volumetric flask. Water was added and sonicated to dissolve it completely and made up to the mark with the same solvent. Further $10 \mathrm{ml}$ of the above stock solution was pipette into a $100 \mathrm{ml}$ volumetric flask and diluted up to the mark with water. The contents were mixed well and filtered through Ultipor N66Nylon 6, 6 membrane sample filter paper. The calibration curve was plotted with the concentrations of the $0.01-0.05 \mathrm{gm} / \mathrm{ml}$ solutions. Calibration solutions were prepared and analyzed immediately after preparation.

Table 1: Chromatographic conditions for Aceclofenac

\begin{tabular}{|c|c|c|}
\hline $\begin{array}{c}\text { S. } \\
\text { No }\end{array}$ & H.P.L.C Conditions & Result \\
\hline 1 & Elution & ISOCRATIC \\
\hline 2 & A.P.I Conc. & $0.01 \mathrm{gm} / \mathrm{ml}$ \\
\hline 3 & Mobile Phase & $\begin{array}{c}\text { Acetonitrile:0.1 M Acetic } \\
\text { Acid(60:40) }\end{array}$ \\
\hline 4 & pH & 3.2 \\
\hline 5 & Column & $\mathrm{C} 18$ \\
\hline 6 & Wavelength & $210 \mathrm{~nm}$ \\
\hline 7 & Flow Rate & $1.2 \mathrm{ml} / \mathrm{min}$ \\
\hline 8 & Runtime & $10 \mathrm{Min}$ \\
\hline 9 & Retention Time & 3.0 \\
\hline 10 & Area & 600.05 \\
\hline 11 & Th.Plates & 4950 \\
\hline 12 & Tailing Factor & 1.007 \\
\hline 13 & Pump Presure & $105 \mathrm{kgf}$ \\
\hline
\end{tabular}

\section{Method Validation procedure}

The objective of the method validation is to demonstrate that the method is suitable for its intended purpose as it is stated in ICH guidelines. The method was validated for linearity, precision, accuracy, specificity, and limit of detection, limit of quantification, robustness and system suitability.

\section{Linearity}

Table 2: Linearity of Aceclofenac

\begin{tabular}{|c|c|c|}
\hline S.NO & CONC & AREA \\
\hline 1 & $0.01 \mathrm{gm} / \mathrm{ml}$ & 600.050 \\
\hline 2 & $0.02 \mathrm{gm} / \mathrm{ml}$ & 1232.876 \\
\hline 3 & $0.03 \mathrm{gm} / \mathrm{ml}$ & 1890.788 \\
\hline 4 & $0.04 \mathrm{gm} / \mathrm{ml}$ & 2499.123 \\
\hline 5 & $0.05 \mathrm{gm} / \mathrm{ml}$ & 3099.006 \\
\hline
\end{tabular}

The developed method has been validated as per ICH guidelines.Solutions of Aceclofenac in the mass concentration range of $0.01 \mathrm{gm} / \mathrm{ml}$ to $0.05 \mathrm{gm} / \mathrm{ml}$ was injected into the chromatographic system. The chromatograms were developed and the peak area was determined for each concentration of the drug solution. Calibration curve of Aceclofenac was obtained by plotting the peak area ratio versus the applied concentrations of Aceclofenac. The linear correlation coefficient was found to be 0.9998
Table 3: Linear Regression Data for Calibration curve

\begin{tabular}{|c|c|}
\hline Drug & Paracetamol \\
\hline Concentration range & $0.01-0.05 \mathrm{gm} / \mathrm{ml}$ \\
\hline Slope $(\mathrm{m})$ & 63312.15 \\
\hline Intercept $(\mathrm{b})$ & -32.41 \\
\hline Correlation coefficient & 0.9998 \\
\hline
\end{tabular}

\section{Precision}

Repeatability of the method was checked by injecting replicate injections of $0.01 \mathrm{gm} / \mathrm{ml}$ of the solution for five times on the same day as intraday precision study of and the RSD was found to be 0.1238 for intraday and 0.1162 for interday

Table 4: Precision parameters of Aceclofenac

\begin{tabular}{|c|c|c|c|}
\hline Injection & Concentration & Intra Day & Inter Day \\
\hline 1 & $0.01 \mathrm{gm} / \mathrm{ml}$ & 599.752 & 603.105 \\
\hline 2 & $0.01 \mathrm{gm} / \mathrm{ml}$ & 599.133 & 604.099 \\
\hline 3 & $0.01 \mathrm{gm} / \mathrm{ml}$ & 599.990 & 603.433 \\
\hline 4 & $0.01 \mathrm{gm} / \mathrm{ml}$ & 600.254 & 605.072 \\
\hline 5 & $0.01 \mathrm{gm} / \mathrm{ml}$ & 600.585 & 604.272 \\
\hline 6 & $0.01 \mathrm{gm} / \mathrm{ml}$ & 600.802 & 604.089 \\
\hline \multicolumn{4}{|c}{} \\
\hline $\mathrm{RSD}$ & 0.1005 & 0.1005 \\
\hline
\end{tabular}

\section{Accuracy}

The accuracy of the method was determined by calculating recovery of Aceclofenac by the method of standard addition. Known amount of Aceclofenac (0.01) was added to a prequantified sample solution and the amount of Aceclofenacl was estimated by measuring the peak area ratios and by fitting these values to the straight line equation of calibration curve. The recovery studies were carried out three times over the specified concentration range and amount of Aceclofenac was estimated by measuring the peak area ratios by fitting these values to the straight line equation of calibration curve.

\section{Specificity}

The specificity of the method was determined by comparing test results obtained from analysis of sample solution containing excipients with that of test results those obtained from standard drug.

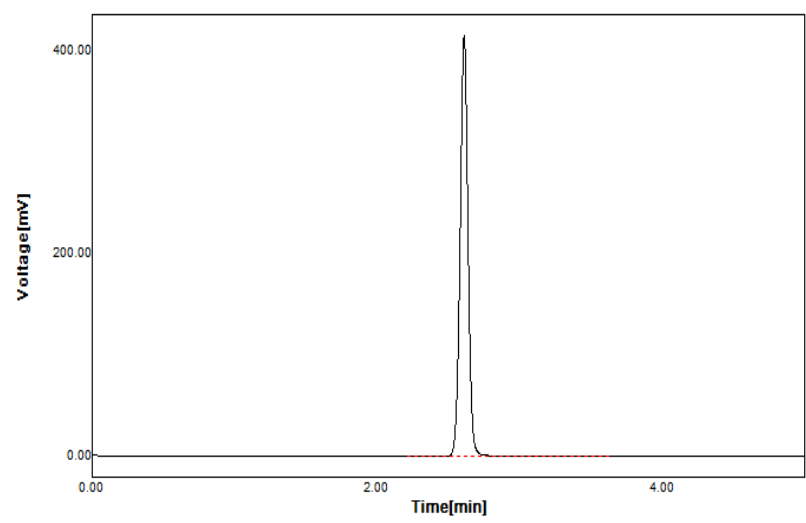

Figure: Typical chromatogram of Aceclofenac

\section{LOD and LOQ}

Limit of detection (LOD) and limit of quantification (LOQ) were calculated as $1 \mathrm{ppm}$ and $10 \mathrm{ppm}$ respectively as per ICH guide-lines. Results are shown in table 5. 


\section{International Journal of Science and Research (IJSR) \\ ISSN (Online): 2319-7064}

Index Copernicus Value (2015): 78.96 | Impact Factor (2015): 6.391

Table 5: Results of LOD and LOQ.

\begin{tabular}{|c|c|}
\hline Parameter & Measured \\
\hline LOD & $0.001 \mathrm{gm} / \mathrm{ml}$ \\
\hline LOQ & $0.01 \mathrm{gm} / \mathrm{ml}$ \\
\hline
\end{tabular}

\section{Robustness}

To determine the robustness of the method, two parameters from the optimized chromatographic, Conditions were varied. First, Instrument and place were changed and second mobile phase concentration was changed $0.1 \mathrm{M}$ to $0.2 \mathrm{M}$, $0.05 \mathrm{M}$. Results of Robustness are shown in table $6 \& 7$.

Table 6: Robustness parameters

\begin{tabular}{|c|c|}
\hline Parameter & Modification \\
\hline M.PHASE & Acetonitrile:0.05M Acetic Acid(60:40) \\
\hline PH & 3.5 \\
\hline WAVELENGTH & $210 \mathrm{~nm}$ \\
\hline R.T & $2.503 \mathrm{Min}$ \\
\hline
\end{tabular}

Table 7: Robustness results

\begin{tabular}{|c|c|}
\hline Accuracy & Precision \\
\hline 570.133 & 567.244 \\
\hline 573.133 & 566.999 \\
\hline 573.159 & 567.230 \\
\hline & 566.847 \\
\hline & 566.990 \\
\hline & \\
\hline RSD: 0.304 & RSD: 0.032 \\
\hline
\end{tabular}

\section{System Suitability Parameter}

System suitability tests were carried out on freshly prepared standard stock solutions of Aceclofenac and it was calculated by determining the standard deviation of Aceclofenac standards by injecting standards in five replicates at 5 minutes interval and the values were recorded in Table 8.

Table 8: System suitability parameters of Aceclofenac

\begin{tabular}{|c|c|}
\hline Parameters & Values \\
\hline$\lambda \max (\mathrm{nm})$ & $210 \mathrm{~nm}$ \\
\hline Correlation coefficient & 0.9997 \\
\hline Retention time & $2.850 \mathrm{~min}$ \\
\hline Theoretical plates & 4950 \\
\hline Tailing factor & 1.009 \\
\hline Limit of detection & $0.001 \mathrm{gm} / \mathrm{ml}$ \\
\hline Limit of quantification & $0.01 \mathrm{gm} / \mathrm{ml}$ \\
\hline
\end{tabular}

\section{Result and Discussion}

\section{Optimization of the chromatographic conditions:}

The nature of the sample, its molecular weight and solubility decides the proper selection of thestationary phase. The drug Aceclofenac being non-polar is preferably analyzed by reverse phase columns and accordingly C18 column was selected. So the elution of the compound from the column was influenced by polar mobile phase. Different mobile phases were tried but satisfactory separation, well resolved and good symmetrical peaks were obtained with the mobile phase Acetonitrile: 0.1M Acetic Acid (60:40).The retention time of Aceclofenac was found to be $3.0 \mathrm{~min}$, which indicates a good base line. The RSD values for accuracy and precision studies obtained were less than $2 \%$ which revealed that developed method was accurate and precise.

\section{Conclusion}

A validated RP-HPLC method has been developed for the determination of Aceclofenac in bulk form. The proposed method is simple, rapid, accurate, precise and specific. Its chromatographic run time of 6 min allows the analysis of a large number of samples in short period of time. Therefore, it is suitable for the routine analysis of Aceclofenac in pharmaceutical analysis.

\section{References}

[1] Karmoker, J.R.; Sarkar, S.; Joydhar, P.; Chowdhury, S.F. (2016). "Comparative in vitro equivalence evaluation of some Aceclofenac generic tablets marketed in Bangladesh" (PDF). The Pharma Innovation Journal. 5: 03-07. Retrieved 2016-09-01.

[2] www.wikipedia.com

[3] www.shreejipharma.co.in/aceclofenac.html

[4] Aceclofenac Tablets. Aceclofenac for Pain Relief | Patient

[5] patient.info/in/medicine/aceclofenac-tablets-for-painand-inflammation-preservex

[6] R. Gopinath, S. Rajan, S. N. Meyyanathan, N. Krishnaveni and B. Suresh "A RP-HPLC method for simultaneous estimation of paracetamol and aceclofenac in tablets", Indian J. Pharm. Sci., 2007, 69 (1): 137-140 DOI: $10.4103 / 0250-474 X .32130$

[7] Prasanna Reddy Battu and MS Reddy, " RP-HPLC Method for Simultaneous Estimation of Paracetamol and Ibuprofen in Tablets", Asian J. Research Chem. 2(1): Jan.-March, 2009 ISSN 0974-4169

[8] B.Gowramma, S. Rajan, S. Muralidharan, S. N. Meyyanathan and B. Suresh " A Validated RP-HPLC method for simultaneous estimation of paracetamol and diclofenac potassium in pharmaceutical formulation", international journal of chemtech research coden( usa): ijcrgg issn : 0974-4290 vol.2, no.1, pp 676-680, jan-mar 2010

[9] ICH, Q2A Text on Validation of Analytical Procedures, International Conference on Harmonization. October 1994.

[10]ICH, 3QB Validation of Analytical Procedures: Methodology, International Conference on Harmonization. November 1996

[11] Indian Pharmacopiea, 1997

[12] European pharmacopoeia 5.0 